Industrial Marketing Management, 2012, Volume 41, Issue 3, Pages 495-507

\title{
Using cross-functional, cross-firm teams to co-create value: The role of financial measures
}

\author{
Matias G. Enz ${ }^{a, *}$, Douglas M. Lambert ${ }^{b}, 1$ \\ ${ }^{a}$ Cranfield School of Management, Cranfield University, Bedfordshire, MK43 OAL, UK \\ ${ }^{b}$ Department of Marketing and Logistics, Fisher College of Business, The Ohio State University, \\ Columbus, $\mathrm{OH} 43210$, USA
}

* Corresponding author. Tel.: +44 1234 751122x2420; fax: +44 1234 752158. E-mail addresses: matias.enz@cranfield.ac.uk (M.G. Enz), lambert.119@osu.edu (D.M. Lambert).

${ }^{1}$ Tel.: + 1614292 0331; fax: +16142920440.

Increasingly, the involvement of representatives from all major business functions in crossfunctional, cross-firm teams is being viewed as a means to develop and maintain profitable business-to-business relationships. However, if the measurements of the value co-created in these relationships with customers and suppliers do not incorporate the financial outcomes of joint cross-functional initiatives, managers can be led to make decisions that jeopardize the long-term profitability of the two firms. In this paper, the authors explore the differences in value cocreation when a company is linked to key customers and key suppliers through cross-functional teams and when it is not. Using a case study approach, the authors measured value co-creation in financial terms and describe how managers changed their behaviors toward customers and suppliers when they were able to compare the value that was being co-created in each relationship. In each pair of relationships, one involved cross-functional teams and the other did not. The results indicate that cross-functional, cross-firm involvement leads to increased value cocreation. The research suggests that marketing scholars and managers should emphasize the use of cross-functional teams that involve all major functions to manage relationships with key customers, and should incorporate financial measures in the evaluation of relationship performance.

Keywords: Cross-functional teams, Relationship marketing, Financial measurement of value cocreation, Interorganizational collaboration, Joint innovation initiatives 


\section{Introduction}

Faced with increased pressure to reduce costs and improve revenues, managers are looking for opportunities to co-create value with customers and suppliers (Cova \& Salle, 2008; Payne, Storbacka, \& Frow, 2008; Ulaga \& Eggert, 2006). Value is co-created when the parties involved in a buyersupplier relationship combine their knowledge and skills in order to achieve higher profits than would be achieved by working independently (Ramirez, 1999). In a business-to-business context, knowledge and skills reside in the functions of the companies involved in the relationship. Thus, the interaction of managers representing multiple organizational functions from both sides of a relationship is paramount for the co-creation of value (Håkansson \& Ford, 2002; Lambert \& GarcíaDastugue, 2006). This interaction should not be limited to representatives from the sales, marketing, and IT functions, as is commonly specified in the marketing literature (Payne \& Frow, 2005), but should include representatives of other functions such as Finance, Logistics, Operations, Purchasing, and R\&D (Lambert, 2010).

In a business-to-business context, marketing managers need to redefine the ways in which they interact with individuals from their own company and from other companies, and incorporate financial measures when evaluating the value created in the relationships with customers and suppliers (Ford \& McDowell, 1999; Lindgreen \& Wynstra, 2005). Customer profitability measures, which should inform customer segmentation and resource commitment decisions, need to capture the value that each customer helps to co-create (Ulaga, 2003). Similarly, the value that each supplier co-creates for a firm by participating in initiatives such as the development and commercialization of new products, the provision of consumer market intelligence, and the delivery of other marketingrelated services, should be quantified and should inform purchasing decisions (Eggert \& Ulaga, 2010). The lack of financial measures of value co-creation prevents managers from identifying the true benefit of cross-functional involvement in long-term buyer-supplier relationships (Hogan, 2001; Rust, Ambler, Carpenter, Kumar, \& Srivastava, 2004).

The value that is co-created in a business-to-business relationship is difficult to assess because it is a multidimensional construct (Ulaga, 2003) and perceptual in nature (Anderson, Jain, \& Chintagunta, 1993). Perceptions of the value created usually differ among individuals from different functions and from different sides of the relationship (Baba, 1988; Ulaga \& Chacour, 2001). Managers' perceptions of value co-creation should be informed by financial information in order to make sound decisions about how to manage relationships with customers and suppliers (Ford \& McDowell, 1999; Ryals, 2005).

In this paper, we explore the differences in value co-creation when a company is linked to key customers and key suppliers through cross-functional teams and when it is not. We propose an approach for quantifying value co-creation in buyer-supplier relationships that captures the financial outcomes from joint initiatives in a single financial measure: revenue minus the 
avoidable costs associated with the initiatives conducted within a relationship. We used the approach to quantify value co-creation in two pairs of buyer-supplier relationships. In each pair, one relationship involved cross-functional teams and the other did not. Based on an analysis of how managers' behaviors changed toward customers and suppliers when quantitative measurements of value co-creation were made available to them, we found that cross-functional involvement resulted in more profitable buyer-seller relationships, and that having financial measurements of value co-creation enabled managers to better allocate resources to relationships.

\section{Literature review}

In the article "Marketing Renaissance," fourteen distinguished marketing scholars provided their insights on the "opportunities and imperatives for improving marketing thought, practice and infrastructure" (Brown et al., 2005). Multifunctional coordination and measurement of the impact of marketing decisions on profits were identified as two research imperatives. One of the essays by Stephen W. Brown summarized a roundtable discussion with senior executives about who is responsible for the firm's relationships with customers: "Executives noted that the customer must be a shared responsibility throughout the organization. Notably, none of the executives mentioned marketing as being responsible for the customer" (p. 3). In another essay, Jagdish N. Sheth and Rajendra S. Sisoda stated that: "marketers have historically focused on sales related measures such as market share, but have largely ignored profitability and shareholder value. Marketing must do a better job managing its resources and demonstrating the value of investing in marketing programs" (p. 12). Next, we review the literature related to these two imperatives for improving marketing thought and practice: 1) a multifunctional approach to marketing, and 2) an emphasis on measuring the financial outcomes of marketing initiatives.

\subsection{Imperative 1: a multifunctional approach to marketing}

In order to successfully identify and satisfy customer needs and strengthen customer relationships, a market orientation should be adopted by all functions of an organization (Jüttner, Christopher, \& Baker, 2007; Narver \& Slater, 1990). However, managers in the marketing function have traditionally seen themselves - and have been seen by managers in other functions - as the ones responsible for creating and maintaining relationships with business-to-business customers (Brown et al., 2005; Webster, 1992). This legacy has its roots in the microeconomic maximization paradigm that dominated management and academic thinking until the late 1980s (Vargo \& Lusch, 2004). During this period of relative stability, competitive advantage was achieved by a focus on transactional efficiencies, which made an emphasis on business functions a reasonable option. Another reason for thinking that the marketing function is responsible for creating, maintaining and strengthening relationships with business-to-business customers is because traditionally it has this responsibility with 
consumers (Lambert, 2010). A single point of contact between two companies is still suitable for relationships that are not key, where the potential financial gains do not justify the costs of implementing cross-functional teams (Lambert, 2010; McDonald, Rogers, \& Woodburn, 2000). But even in these cases, a cross-functional team should develop the Product and Service Agreement that the salesperson delivers. As competition increasingly is based on the provision of services and on the development of close relationships with key customers and suppliers, the need for actively involving multiple corporate functions in key business-to-business relationships increases (Ryals \& Knox, 2001; Tuli, Kohli, \& Bharadwaj, 2007).

Without the active involvement of the major business functions in a relationship, the crossfunctional interfaces between the two companies may not be sufficiently developed to facilitate the dialog and the exchange of services that is necessary to co-create value (Lambert \& GarcíaDastugue, 2006). When this happens, marketing strategies are not enriched with knowledge about customer needs that could have been developed if other functions had been involved (Narver \& Slater, 1990). Marketing may have a key role in making promises and finding new business, but the satisfaction of promises and the building of customer loyalty are the result of the coordinated actions of individuals in multiple functions (Brown et al., 2005).

While there is a recognition in the Customer Relationship Marketing (CRM) and Key Account Management (KAM) literature that a cross-functional approach is desirable in key business-tobusiness relationships, in many cases it is limited to the so called "front-end" functions such as sales, communications, IT, and new business development (Lambert, 2010). "Although CRM requires a cross-functional approach, it is often vested in functionally based roles, including IT and marketing" (Payne \& Frow, 2005, p. 170). A growing number of scholars are supporting the view that the implementation of cross-functional business processes is key to achieving competitive advantage (Lambert, 2010; Storbacka, Ryals, Davies, \& Nenonen, 2009). Research on team and group management provides insights about the factors that influence team performance and about how to design teams (e.g., Campion, Medsker, \& Higgs, 1993; Hackman, 1987; Hirunyawipada, Beyerlein, \& Blankson, 2010). However, most research focuses on team dynamics that occur within a single company (Trent \& Monczka, 1994). Research that involves the interaction of cross-functional teams with members that belong to two independent companies is rare (Troy, Hirunyawipada, \& Paswan, 2008). In this paper, we identify the benefits in terms of value co-creation that are possible by using cross-functional teams in key buyer-seller relationships. The conceptualization of cross-functional teams used in this paper is much broader than what is normally used in the marketing literature because we included teams with representation from functions such as Finance, Logistics, Operations, Purchasing, and R\&D, as well as Sales, Marketing and IT. 


\subsection{Imperative 2: an emphasis on measuring the financial outcomes of marketing initiatives}

Scholars and practitioners are under increased pressure to demonstrate how marketing assets and capabilities impact business performance (Helgesen, 2007; Kumar \& Shah, 2009). Marketers have historically focused on macro financial measurements such as return on capital, accounts receivable, and operating expenses, which are not sufficient to link a firm's long-term strategy with its shortterm actions (Kaplan \& Norton, 1996; Rust et al., 2004). Typically, companies do not have disaggregated financial information that provides a meaningful and current picture of the value that is being co-created within relationships with customers and suppliers (Brown et al., 2005; Doyle, 2000), and this is the type of information that managers need to make difficult decisions. A manager that we interviewed as part of this research said: "What is key for partnerships is measuring the total dollar value of the relationship, or trying to estimate the total dollar value. Because it is hard to do." An R\&D manager from another firm commented: "It would be great if there was a model to figure out how we measure the value that we bring to the relationship quantitatively (we were talking about financial measures), but we have not cracked that nut yet."

Ignoring the importance of long-term financial measurements for making strategic decisions such as customer and supplier segmentation in business-to-business contexts can lead to: 1) the prioritization of customer segments based on revenue and not on the current and future potential for value co-creation, 2) the elimination of services that would increase customer loyalty for costsavings reasons, 3 ) the allocation of business to suppliers based on price or total cost measures without consideration of the total value that each supplier could provide, and 4) the provision of different levels of service to the same customer by different business units (Lambert, 2008; Ulaga, 2003). Without holistic financial measurements of the benefits of working in cross-functional, crossfirm teams with customers and suppliers, managers often have to rely on perceptions of value to make strategic decisions (Lindgreen \& Wynstra, 2005). Perceptions play an important role in strategic decision making because a significant proportion of the market value of firms lies in intangible off-balance-sheet assets, such as brands, market networks, and intellectual property (Rust et al., 2004). However, managers may modify their perceptions if provided with the financial measurements of a relationship's performance (Ford \& McDowell, 1999; Ryals, 2005). In this exploratory research, we focused on how managers changed their behaviors toward their customers and suppliers when they were provided with financial measures of the value that was being cocreated through cross-functional initiatives in each relationship.

Typically, scholars measure the impact of marketing strategies on business performance using surveys designed for a single respondent from a single organization in the relationship, and the data gathered are based on subjective measurements of performance. Single-respondent surveys are insufficient when used to investigate the value co-created in business-to-business relationships because they do not adequately capture multi-functional and multi-organizational issues (Baba, 
1988; Stuart, McCutcheon, Handfield, McLachlin, \& Samson, 2002). In addition to perceptual measurements, managers on both sides of the relationship need objective financial information to make sound decisions about how to manage suppliers and customers (Ryals, 2005).

As advocated by Vargo and Lusch (2004) in their article, "Evolving to a New Dominant Logic for Marketing," when the capabilities that exist in organizational functions on both sides of the relationship are combined through cross-functional teams, it is expected that more value is co-created. As in every business relationship there is always a customer and a supplier, value co-creation should be measured not only in customer relationships but also in supplier relationships (Sheth \& Sharma, 1997). There is a need for research that demonstrates in financial terms, the incremental value that can be co-created using cross-functional teams with key customers and suppliers (Brown et al., 2005).

In this exploratory research, we address the two imperatives for improving market research and practice that were identified by Brown et al. (2005). Using a case study approach, we compared the value co-created in pairs of buyer-supplier relationships that differed in terms of the involvement of individuals in cross-functional, cross-firm teams (Imperative 1). In each relationship, we quantified in financial terms the value co-created (Imperative 2). Value co-creation was measured from the point of view of the customer in a pair of supplier relationships and from the point of view of the supplier in a pair of customer relationships. This enabled the comparison of financial outcomes when cross-functional teams were used, and when they were not. We added a longitudinal dimension by describing how managers' behaviors toward the relationships changed during the year after the financial information was made available to them. In the next section, we describe the case study approach used.

\section{Methodology}

The main goal for this research was to explore the differences in value co-creation when a company is linked to key customers and key suppliers through cross-functional teams and when it is not. Indepth case studies were conducted in four buyer-supplier relationships. The case study approach is an empirical inquiry used to investigate a contemporary phenomenon within its real-life context (Meredith, 1998; Yin, 1989). Its use for buyer-supplier relationships research has been gaining acceptance during the last decade (Beverland \& Lindgreen, 2010).

The case study approach was chosen as the research methodology for two primary reasons. First, the measurement of the value co-created by firms engaged in cross-functional relationships has not received much research attention (see the Literature review section). The case study approach is recommended when little is known about the phenomena and when the research is exploratory (Eisenhardt, 1989; Ellram, 1996; Yin, 1989). Second, in business-to-business research there is 
usually no single source of information that represents the point of view of the organization as a whole, so special consideration has to be given to the identification of the key respondents (Phillips, 1981). Individuals from different companies, from different functions within a company, and from different organization levels in a company, may have different perspectives about the issues related to the co-creation of value (Lincoln \& Zeitz, 1980; Ulaga \& Chacour, 2001). In order to increase the trustworthiness of the results, we gathered information from representatives of all the functions that participated in cross-functional teams and from different organizational levels. Case study research has proven to be more appropriate than statistical methods for exploring situations involving multiple respondents (Baba, 1988; Eisenhardt, 1989). In the case study approach, the unit of analysis does not correspond to a sampling unit and should not be chosen randomly as in statistical methods (Yin, 1989). A theoretical sampling approach was used to select cases in a controlled fashion (Ragin, 1987; Yin, 1989). An embedded case study design with three units of analysis was chosen for this research. An embedded case study design involves more than one unit of analysis to give attention to different aspects of the phenomena under study (Yin, 1989). The first unit of analysis was defined at the buyer-supplier relationship level. Two pairs of relationships were compared. The second unit of analysis was at the cross-functional team level. Within each relationship, the dynamics of different cross-functional teams were investigated. The third unit of analysis was at the individual level. The individuals that participated in each team were interviewed. The data collection involved different sources of evidence. Interviews with managers from different companies and organizational functions were used to identify cross-functional team initiatives. Other sources of evidence were documentation and direct observation of how managers interacted with their suppliers or customers. Financial data were used to measure value co-creation. The use of multiple sources of evidence helped to gather richer perspectives about the phenomenon and enhance the trustworthiness of the results (Yin, 1989).

\subsection{Validation requirements}

Rigor in the validation procedures in case study research is critical because of the level of subjectivity involved, the risk of researcher bias, the concerns about generalizability, and the risk of low parsimony are higher than in quantitative research. Yin (1989) proposed four tests to increase the validity of case study research: 1) construct validity, 2) internal validity, 3) external validity, and 4) reliability. A description of the tactics used to increase validity follows.

1) Construct validity is achieved if the researcher's understanding of the concepts being studied genuinely reflects the views of the respondents. The tactics used for increasing construct validity were: the usage of multiple sources of evidence and the review of the draft case study report by key informants. When a new concept emerged, its meaning was discussed with the interviewee and in subsequent interviews to ensure a common interpretation. At the end of the data collection stage, a draft of the case study report was sent to the managers for review in order to confirm that 
their opinions were accurately reflected.

2) Internal validity is achieved when the causal relationships between variables are accurately identified. The tactics used were pattern-matching and rival explanations (Miles \& Huberman, 1994). Pattern matching consists of comparing an empirically based pattern with a predicted one. If the patterns coincide, internal validity is strengthened. The predicted pattern was that value cocreation (measured in financial terms) would be higher in cross-functional relationships. The proposition was supported with the financial data that were collected. Rival explanations of value cocreation were tested. For example, it was theorized that the volume of sales in a relationship could be a more important driver of value co-creation than cross-functional involvement. The rival explanation was discarded when both relationships with lower business volume and crossfunctional involvement were found to be co-creating more value.

3) External validity is defined as the extent to which the findings can be generalized. The research needs to be designed to increase its applicability to other situations and establish the domain to which the findings can be extrapolated. The tactic used was to compare the findings with existing theory (Yin, 1989).

4) Reliability is achieved if the research can be replicated in a different sample, and the same results are obtained. For this purpose, clear documentation of the research steps was maintained using a research protocol and by developing a research database. The protocol contained the directions that had to be followed during the data collection phase (Eisenhardt, 1989). Pilot case studies were used for testing and refining the methodology with managers from organizations that did not participate in the formal research (Yin, 1989).

\subsection{Sample characteristics}

For the purpose of this study, a cross-functional and cross-firm team was operationalized as a group of individuals from each company representing different organizational functions, which are brought together to conduct an initiative. The teams could have been created for either an ongoing assignment or a discrete project with a specific goal. There were multiple projects, which included teams that participated in product development, cost reduction, or revenue generation initiatives.

A total of six companies were included in the research. In order to protect their identities they are identified as Company A, Company B, Company C, Company D, Company E, and Company F. The six firms formed four buyer-supplier relationships: 1) Relationship $A B$, between the customer Company $A$ and the supplier Company $B, 2$ ) Relationship AC, between the customer Company $A$ and the supplier Company $C, 3$ ) Relationship DE, between the supplier Company $D$ and the customer Company $E$, and 4) Relationship DF, between the supplier Company D and the customer Company $\mathrm{F}$. 
Company A was a full-service restaurant chain that owned and operated more than 500 restaurants in the United States. The company's revenues were in excess of $\$ 1$ billion. Company A's management considered Company $B$ and Company $C$ to be strategic suppliers. The products supplied by Company $\mathrm{B}$ and Company $\mathrm{C}$ belonged to similar categories, and they both represented a significant volume of purchases for Company $A$. The major difference between the two relationships was that managers in Relationship $A B$ regularly participated in cross-functional teams, while managers in Relationship AC did not. Company B was a global food company with annual revenues of more than $\$ 40$ billion. The research was conducted in a division dedicated to serve the food service industry. The total sales from Company B to Company A were $\$ 16.7$ million in 2008. Company C was an international provider of food products with annual revenues in excess of $\$ 40$ billion. The research was conducted in a business unit that provided products and services for the restaurant industry. The total sales from Company C to Company A were $\$ 18.5$ million in 2008.

Company $\mathrm{D}$ was a food products company that sold refrigerated grocery and fresh meat products. The products were sold in more than 15,000 grocery stores in 49 U.S. states. The company's revenue was more than $\$ 250$ million. Company $\mathrm{E}$ and Company $\mathrm{F}$ were retailers which were considered strategic to Company D's management, and both represented a significant volume of Company D's sales. Company $\mathrm{E}$ was a supermarket chain with annual sales of more than $\$ 5$ billion. Company $\mathrm{E}$ bought $\$ 14.5$ million of Company D's products in 2008. Company $F$ was a supermarket chain with annual sales of more than $\$ 15$ billion. Company $D$ 's sales to Company $F$ were $\$ 43.0$ million. The major difference between the two relationships was that managers in Relationship DE participated regularly in cross-functional teams, while managers in Relationship DF did not.

The research was designed to control for the effects of the importance of the relationships on the measurement of value co-creation. Strategic suppliers or strategic customers tend to be managed with a more cross-functional approach than the less strategic customers or suppliers (Lambert, 2010; McDonald et al., 2000). This may lead to the question: Are higher measurements of value co-creation due to the existence of cross-functional, cross-firm teams, or are they due to the fact that the relationships were more important and thus received more attention from management? To ensure internal validity, we used a theoretical sampling approach (Yin, 1989) based on the principles of Qualitative Comparative Analysis (Ragin, 1987). Managers in Company A were asked to identify a pair of relationships with suppliers of similar products that were considered strategic and that represented a significant volume of purchases. Managers in Company D were asked to select a pair of customers that both represented a significant volume of sales of key commodities and a high potential for growth. Perceptions about the importance of the relationships within each pair were validated with managers from various functions. As shown in Table 1, the relationships with higher sales volume or purchase volume, were the ones where cross-functional, cross-firm teams had not been implemented. Therefore, if value co-creation was higher in Relationship 
$A B$ and Relationship $D E$, we could conclude that cross-functional, cross-firm involvement was the factor that drove increased value co-creation and not the volume of business involved.

\subsection{Identification of respondents}

For each interorganizational relationship, management was asked to identify cross-functional teams. Managers identified the functional representatives that interacted with individuals from the other company. The individuals identified were interviewed and a snowball technique was used (Miles \& Huberman, 1994). Following the approach used by Carter, Ellram, and Tate (2007), the individuals were asked to identify others with whom they communicated on at least a monthly basis regarding to the team's activities. A total of 46 managers were interviewed: nine from Company A, seven from Company $B$, eleven from Company $C$, ten from Company $D$, eight from Company $E$, and one from Company $F^{2}$. Managers represented functions such as: 1) R\&D (nine informants), 2) Logistics (eight informants), 3) Sales (seven informants), 4) Operations (five informants), 5) Marketing (four informants), 6) Procurement (four informants), 7) and Finance (four informants) among other functions (5 informants).

Table 1 Relationship cases selected using a theoretical sampling approach.

\begin{tabular}{llll}
\hline Relationship & $\begin{array}{l}\text { Sales/purchase volume in } \\
2008\end{array}$ & $\begin{array}{l}\text { Existence of cross- } \\
\text { functional cross- } \\
\text { firms teams }\end{array}$ \\
\hline AB & $\begin{array}{l}\text { Purchases from Company A to } \\
\text { Company B: } \$ 16.7 \text { million }\end{array}$ & Lower & Yes \\
AC & $\begin{array}{l}\text { Purchases from Company A to } \\
\text { Company C: } \$ 18.5 \text { million }\end{array}$ & Higher & No \\
\hline DE & $\begin{array}{l}\text { Sales from Company D to } \\
\text { Company E: } \$ 14.5 \text { million }\end{array}$ & Lower & Yes \\
DF & $\begin{array}{l}\text { Sales from Company D to } \\
\text { Company F: } \$ 43.0 \text { million }\end{array}$ & Higher & No \\
& & & \\
\hline
\end{tabular}

The interviews were conducted in person and lasted an average of 47.5 minutes. A typical interview started with a short overview of the research and an explanation of the methodology prior to beginning the formal questioning. All the interviewees agreed to be recorded. An interview guide was used and interviewees were asked about the initiatives in which he/she interacted with individuals from the

\footnotetext{
2 Company F's buyer was the single point of contact between Company D and Company F. 5) quantify the revenues and costs associated with the joint initiatives, 6) analyze the financial data, track performance, and make decisions, and 7) set goals for value co-creation. Fig. 1 describes the method for measuring value co-creation. Next, an explanation of each step of the method is provided.
} 
customer or supplier firm. In order to better assess the value that was co-created in the cross-functional initiatives, each interviewee was asked to provide supporting documentation whenever possible. The documentation, which was stored in the research database, included project plans, project reports, financial estimations of costs and benefits, internal memos, and performance assessments. At the end of the interview, the interviewees were asked to identify other individuals that participated both formally or informally on the cross-functional team. Additionally, the researcher participated in team meetings as an observer. The audio recordings were transcribed verbatim. Both the audio recordings and the transcriptions were stored in the research database.

\subsection{Method for measuring value co-creation}

The data analysis stage started after the first interview and continued in parallel with the remainder of the data collection. The method for measuring value co-creation can be classified as a method of "linking marketing actions to performance" according to Moorman and Lehmann's (2004, p. 3) framework for assessing marketing strategy performance. It was adapted from the customer and supplier profitability reports recommended by Lambert (2008). The adaptations were necessary for three reasons. First, managers in Company A were measuring only the purchase price plus transportation cost associated with relationships $A B$ and $A C$. However, when suppliers are engaged in activities that result in changes in revenue and profit, both total costs of ownership and the financial impact on revenue and profit should be measured (Lambert, 2008). Second, even when customer profitability reports and supplier total cost reports accurately measure profit or total cost, they may not be able to identify the incremental profits or costs associated with specific value co-creation initiatives. An awareness of the financial outcomes from the specific initiatives is needed in order to effectively allocate resources to relationships in the future (Ford \& McDowell, 1999). Third, the financial information available from the companies was not structured as recommended in the literature, making it necessary to determine the revenue and cost data needed to calculate the profitability of the relationships. The method for measuring value co-creation consisted of seven steps: 1 ) identify the joint initiatives conducted in the relationship, and 2) determine if profitability or total cost reports are available. If profitability or total cost reports are available, then step five is next. If profitability or total cost reports are not available, then it is necessary to: 3 ) determine the revenue and cost data that must be obtained, and 4) calculate value co-creation for each side of the relationship. Once value co-creation is measured, 5) quantify the revenues and costs associated with the joint initiatives, 6) analyze the financial data, track performance, and make decisions, and 7) set goals for value co-creation. Fig. 1 describes the method for measuring value co-creation. Next, an explanation of each step of the method is provided.

\subsubsection{Step 1: identify the joint initiatives conducted in the relationship}

The first step was based on the approach used by Ford and McDowell (1999), which consisted of identifying and validating the joint initiatives conducted in each relationship. The 46 interviews with managers were used to identify joint initiatives. Initiatives that involved cross-functional teams and initiatives that did not involve cross-functional teams were identified, and they were categorized in two 
groups: revenue generation initiatives and cost reduction initiatives. Financial information that enabled the quantification of the outcomes was requested. A detailed description of each initiative was kept in the research database.

\subsubsection{Step 2: determine if profitability or total cost reports are available}

Customer and supplier profitability reports provide managers with the financial information needed to make sound decisions. The profitability of a customer (or a customer segment) is calculated using revenues minus avoidable costs. Fixed overhead and costs that are common to multiple customers and are not affected by the way a customer relationship is managed should not be included in the profitability report. The allocation of joint fixed costs to a customer is based on subjective and arbitrary criteria, which distorts the real impact on overall profitability of the firm (Lambert \& Sterling, 1987).

The lack of quality information from a company's accounting system can be a complication when developing customer profitability reports and total cost reports. Two situations are possible. First, managers have developed standard customer profitability reports or total cost reports, have access to all the required information, and can construct them on a regular basis. Managers in this situation have an advantage in estimating value co-creation. In these cases, Step 5 of the method should be followed next. Second, managers do not have customer profitability reports or total cost reports available because they do not have the necessary information or use average costs for some or all of the costs in these reports. In such situations, managers should determine the revenue and cost data that must be obtained (Step 3 of the method).

\subsubsection{Step 3: determine the revenue and cost data that must be obtained}

When the companies' accounting systems are not designed to provide the required information, managers must determine the necessary revenue and the cost data. These data must enable managers to construct the customer profitability report (or the supplier profitability report) as accurately as possible, and to quantify the revenues and costs associated with the joint activities identified in Step 1. First, variable manufacturing costs are deducted from net sales to calculate a manufacturing contribution. Variable marketing and logistics costs are deducted to obtain the contribution margin. Assignable non-variable costs are deducted to calculate a segment controllable margin. A charge for dedicated assets is subtracted to obtain the net segment margin. The steps for constructing supplier profitability reports are similar if the customer is a wholesaler or a retailer. Managers at manufacturing firms should use total cost reports for the suppliers of undifferentiated raw materials. Total cost reports should include the price paid for the products purchased to the supplier plus transportation costs, inventory carrying costs, financial impact of the terms of sale, ordering costs, receiving costs, quality costs, and administrative costs. If there are revenue implications associated with one supplier versus another, such as might be the case if there are differences in product quality or in the level of support provided to develop new products, the associated revenues and costs also must be measured (Lambert, 2008). 


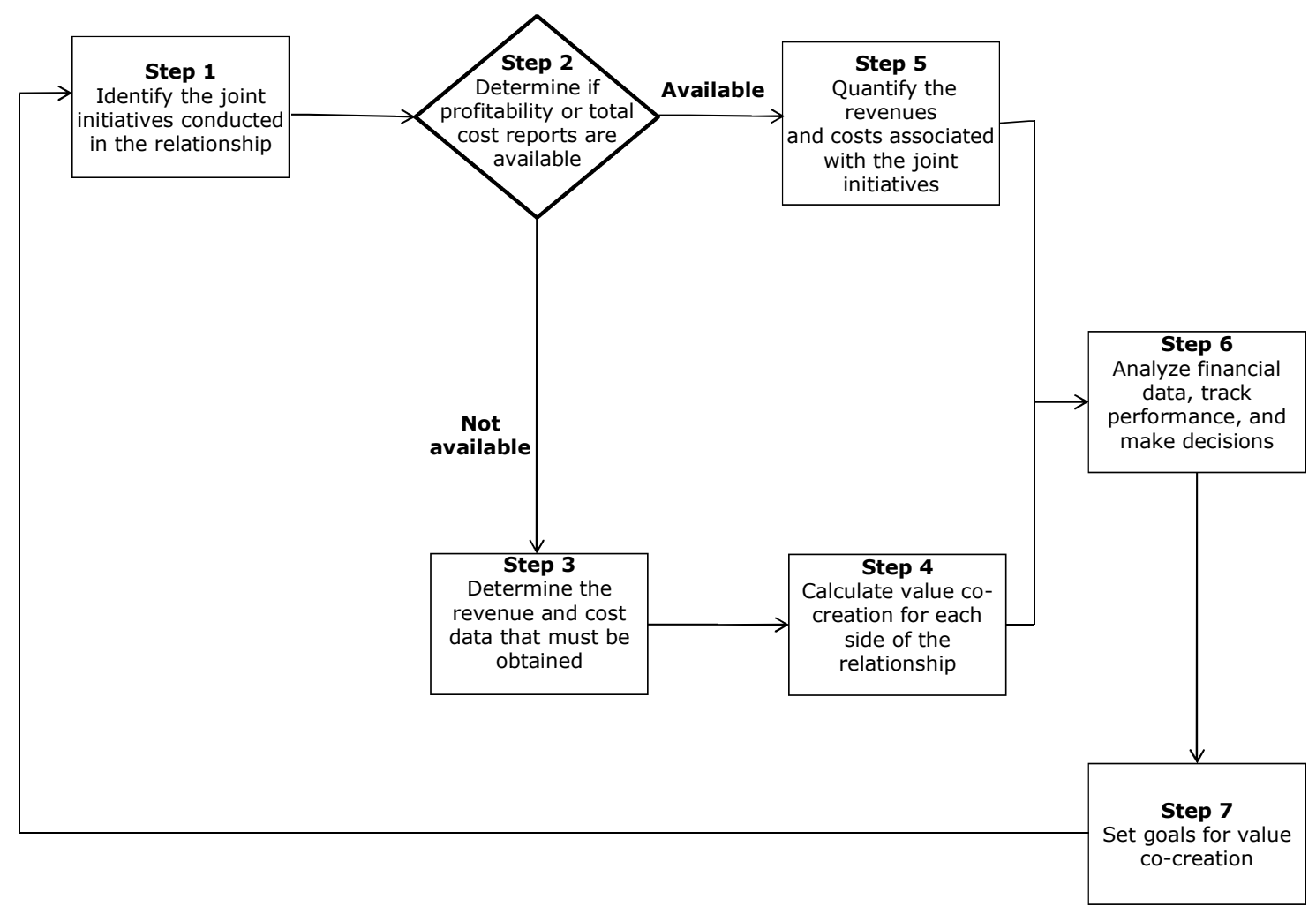

Fig 1. Method for measuring value co-creation.

\subsubsection{Step 4: calculate value co-creation for each side of the relationship}

Once the necessary revenue and cost data were obtained, financial measurements associated with the benefits of the relationships were calculated. When management from both companies share financial information and collaborate in the measurement of value co-creation, fact-based negotiations are enabled (Lambert, 2008). Due to confidentiality issues and lack of trust, managers at some of the participant companies were reluctant to provide financial data. In these cases, an estimate of the benefits was based on data supplied by the other firm. For example, for suppliers that helped a customer with the development and commercialization of a new product, the increase in sales of the raw materials that they provided for the new product was used. The best measure would have been the incremental profitability for the supplier that was generated from the joint initiatives.

\subsubsection{Step 5: quantify the revenues and costs associated with the joint initiatives}

If the accounting system that provides the customer profitability reports and total cost reports does not have the capability to identify the incremental sales or cost reductions that resulted from joint initiatives, an estimation of the value co-created in joint initiatives should be determined in order to have a more complete appreciation of the total value co-created. The fifth step involved the collection of financial information to quantify the outcomes from the initiatives identified in Step 1. For revenue 
generation initiatives, the contribution toward the joint costs and fixed costs was measured. For cost reduction initiatives, the resulting savings were measured. The cost information that was used to quantify the outcomes of revenue generation and cost reduction initiatives did not include the allocation of overhead costs. The allocation of such costs using subjective and arbitrary bases would have distorted the identification of the most profitable customers (Lambert \& Sterling, 1987). The financial outcomes from each initiative identified in Step 1 were calculated for the last three fiscal years (2007, 2008, and 2009), and projected into the next fiscal year (2010). The projections for fiscal year 2010 were based on the sales forecasts and purchase plans provided by managers. In the relationships that we studied no capital investments were made. If financial investments are required by one or the other party, it would be necessary to calculate the net present value of the cash flows over the life of the investment (incremental revenue minus avoidable costs are reasonable approximations of cash flows although the timing associated with receiving revenues and paying expenses might not be exactly the same as these statements) to determine if the initiatives meet the companies' hurdle rates on new investments.

\subsubsection{Step 6: analyze the financial data, track performance, and make decisions}

The decisions about the assignment of resources to a relationship should be based on the potential of a relationship to co-create value. In the sixth step, the financial information was analyzed to identify the relationships where more value was being co-created. The financial measurements of the outcomes from the joint initiatives were combined with the profitability reports or the total cost reports to analyze the value co-created for each company in the relationship.

\subsubsection{Step 7: set goals for value co-creation}

The objective of developing close relationships with key customers and suppliers is to increase value cocreation. With a method for measuring value co-creation, managers can set goals and compare the performance of various relationships. Once the goals are set, Step 1 of the method should be repeated.

\subsection{Longitudinal assessment of the changes in managers' perceptions and behaviors toward the relationships}

In order to provide a longitudinal dimension to our research and to increase internal validity (Eggert, Ulaga, \& Schultz, 2006; Miles \& Huberman, 1994), we interviewed managers 17 months after the financial measurements of value co-creation were provided to them. The Procurement Director and the Executive VP of Supply Chain Management of Company A were asked about how their perceptions and behaviors toward supplier Company B and supplier Company $C$ had changed after they had the financial information available. The President and the VP of Sales of Company D were asked similar questions about the relationships with customer Company $E$ and customer Company $F$. The results are presented in the next section. 


\section{Results}

The method for measuring value co-creation was applied in the two pairs of relationships. In the next sections, the value co-created is measured and compared between relationships with and without crossfunctional involvement.

\subsection{Measurement of value co-creation in Relationship $A B$}

The focus in the relationship between Company $A$ and Company $B$ was on developing new products that could be commercialized at Company $A$. Five products resulted from collaborative initiatives: $A B 1, A B 2, A B 3$, $A B 4$, and $A B 5$. According to the marketing and $R \& D$ managers from Company $A$, these products were new concepts introduced to expand the variety of choice at Company A stores, and they did not replace existing products.

Table 2 Financial outcomes for Company A from joint initiatives in Relationship AB.

\begin{tabular}{|c|c|c|c|c|c|}
\hline \multirow{2}{*}{\multicolumn{6}{|c|}{$\begin{array}{l}\text { Value co-creation for Company A } \\
\text { Revenue generation initiatives }\end{array}$}} \\
\hline & & & & & \\
\hline \multirow{3}{*}{$\begin{array}{l}\text { Product } \\
\text { developed }\end{array}$} & \multirow{3}{*}{$\begin{array}{l}\text { Date } \\
\text { launched }\end{array}$} & \multicolumn{4}{|c|}{ Contribution (*) } \\
\hline & & FY 2007 & FY 2008 & FY 2009 & Projected \\
\hline & & & & & FY 2010 \\
\hline Product AB1 & Winter 2006 & $\$ 3,433,456$ & $\$ 10,084,929$ & $\$ 9,164,521$ & $\$ 8,886,378$ \\
\hline Product $A B 2$ & Fall 2006 & $\$ 17,546,352$ & $\$ 12,679,424$ & $\$ 19,108,192$ & $\$ 16,513,808$ \\
\hline Product AB3 & Fall 2008 & - & - & $\$ 474,508$ & $\$ 474,508$ \\
\hline Product AB4 & Not launched yet & - & - & - & - \\
\hline Product AB5 & Not launched yet & - & - & - & - \\
\hline Total & & $\$ 20,979,808$ & $\$ 22,764,353$ & $\$ 28,747,221$ & $\$ 25,874,693$ \\
\hline
\end{tabular}

Projected co-creation of value for FY 2010: $\$ 25,874,693$.

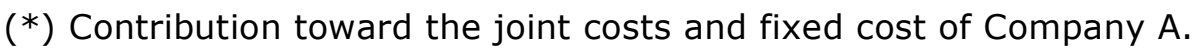

\subsubsection{Value co-creation for Company $A$}

Table 2 shows the financial outcomes for Company A related to the joint initiatives conducted in Relationship $A B$. The commercialization of Product $A B 1$ provided a contribution of $\$ 22.7$ million toward the joint costs and fixed costs of Company A during the previous three fiscal years (\$3.4 million in 2007, $\$ 10.1$ million in 2008 and $\$ 9.2$ million in 2009). The commercialization of Product $A B 2$ generated a contribution of $\$ 49.3$ million in the same period of time ( $\$ 17.5$ million in $2007, \$ 12.7$ million in 2008 , and $\$ 19.1$ million in 2009). Products $A B 1$ and $A B 2$ were part of Company A's offering since they were launched in 2006. In an industry where innovation and the introduction of new products are key, these two products became classics for Company A's consumers. Product AB3 was launched in fall 2008 and during the first six months, the contribution toward the joint costs and fixed costs of Company $A$ was 
$\$ 474,508$. This product was not a core product so it did not reach the same sales levels as products $A B 1$ and $A B 2$. However, being a new concept, it was believed to have affected the consumer's perceptions of innovativeness that management was trying to project. The teams involved in the relationship created a continuous pipeline of new products. Products $A B 4$ and $A B 5$ were developed but had not been launched at the time of this research.

Products $A B 1, A B 2, A B 3, A B 4$ and $A B 5$ were developed with high levels of cross-functional involvement at the stages of idea generation, conceptualization and implementation. In fact, four informants from Company $\mathrm{A}$ agreed that the products would have not existed without the involvement of the managers from Company B. No cost reduction initiatives were identified in this relationship.

Based on the sales forecast from the managers at Company A for the fiscal year 2010, Product AB1 was projected to generate a contribution of $\$ 8.9$ million, Product $A B 2$ was projected to generate a contribution of $\$ 16.5$ million and Product $A B 3$ was projected to generate a contribution of $\$ 0.5$ million. The result from the three revenue generation initiatives for FY 2010 was projected to be $\$ 25.9$ million.

In spite of the extra sales generated for Company $B$ from the introduction of products $A B 1, A B 2$, and $A B 3$, Company $A$ 's total purchases from Company $B$ decreased $\$ 1.0$ million (6\%) in 2009 due to the unfavorable economy. Company $\mathrm{C}$, which was not involved in cross-functional initiatives, was affected more by the bad economy: purchases of Company A from Company C fell $\$ 4.2$ million (23\%) in 2009. For 2010, purchases from Company B and Company C were projected to remain at similar levels to 2009, but this projection was made prior to management in Company A receiving the results from this research.

The 2010 projected value of joint initiatives for Company A with Company B was $\$ 25.9$ million, 1.65 times the total purchases from Company B projected for 2010. This result highlights the importance of measuring the value generated in a relationship and not simply cost, as managers in Company $A$ were doing. With more complete information as a result of this research, managers at Company A placed more emphasis on a supplier's ability to work in cross-functional teams and to focus on value cocreation.

\subsubsection{Value co-creation for Company B}

The measurement of value co-creation for Company $B$ is shown in Table 3. For participating in the revenue generation initiatives that led to the development of products $A B 1, A B 2, A B 3, A B 4$, and $A B 5$, Company $B$ could offset part of the lost sales to company $A$ caused by the bad economy. Product $A B 1$ used two raw materials supplied by Company B: Raw Material 1 and Raw Material 2. The combined increase in sales was $\$ 863,400$ in 2008 (5.2\% of the total sales to Company $A$ that year). Product AB2 was comprised of two raw materials that were provided by Company B: Raw Material 3 and Raw Material 4. The combined increase in sales was $\$ 63,805$ in $2007, \$ 90,665$ in 2008 , and $\$ 36,190$ in 
the first four months of 2009. Product AB3 had a single raw material provided by Company B: Raw Material 5. The increase in sales from the development of Product AB3 was $\$ 243,000$ in the first four months of 2009.

The combined sales increase for Company $B$ from participating in the development of products $A B 1, A B 2$ and $A B 3$ was $\$ 821,805$ in $2007, \$ 954,065$ in 2008 and $\$ 279,190$ in the first four months of 2009 . The sales derived from these cross-functional initiatives represented $5.7 \%$ of Company B's total sales to Company $A$ in 2008. Based on the sales forecast of products $A B 1, A B 2$ and $A B 3$ for fiscal year 2010, the increase in sales for Company $B$ was projected to be $\$ 889,962$ ( $\$ 627,943$ from the raw materials for Product $A B 1$, $\$ 79,769$ from the raw materials for Product $A B 2$, and $\$ 182,250$ from the raw material for Product $A B 3)$. The projected sales from these five raw materials represent $5.7 \%$ of the projected 2010 purchases of Company A from Company B. In addition, due to the value created for the customer, less pressure was placed on company $B$ to reduce its prices relative to competitors.

\subsection{Measurement of value co-creation in Relationship AC}

The relationship between Company $A$ and Company $C$ did not involve cross-functional teams. Managers in Company $A$ and Company $C$ had conflicting expectations and inaccurate perceptions about the level of management's commitment at the other company and did not assign the resources that existed in their company's various functions to the relationship. The participation of Company $C$ in product development activities was limited. The ideas were generated by managers in Company $A$, while managers in Company $C$ were responsible for developing a concept that satisfied the customer requirements. The activities between the companies were coordinated through a sales-person and a buyer. Two new products were developed and three cost reduction initiatives were conducted in Relationship AC.

\subsubsection{Value co-creation for Company $A$}

Two products that were developed in this relationship were commercialized by Company A since 2007 (see Table 4). The contribution of Product AC2 toward the joint costs and fixed cost of Company A in fiscal year 2008 was $\$ 4,883$. In fiscal year 2009, Product AC2 generated a contribution of $\$ 5,722$, while Product AC1 generated a contribution of $\$ 44,226$ since its introduction in fiscal year 2009 . The total contribution projected for 2010 from Products AC1 and AC2 was $\$ 54,461$. 
Table 3 Financial outcomes for Company B from the joint initiatives in Relationship AB.

\begin{tabular}{|c|c|c|c|c|c|}
\hline \multicolumn{6}{|c|}{ Value co-creation for Company B } \\
\hline \multicolumn{6}{|c|}{ Incremental sales to Company A from new products developed collaboratively } \\
\hline \multirow{2}{*}{$\begin{array}{l}\text { Product } \\
\text { developed/raw } \\
\text { material supplied }\end{array}$} & \multirow{2}{*}{$\begin{array}{l}\text { Date } \\
\text { launched }\end{array}$} & \multicolumn{4}{|c|}{ Incremental purchases } \\
\hline & & FY 2007 & FY 2008 & $\begin{array}{l}\text { FY } 2009 \\
\text { (up to May-20) }\end{array}$ & $\begin{array}{l}\text { Projected FY } \\
2010\end{array}$ \\
\hline Product AB1 & Winter 2006 & & & & \\
\hline Raw material 1 & & $\$ 616,000$ & $\$ 693,000$ & - & $\$ 504,013$ \\
\hline Raw material 2 & & $\$ 124,000$ & $\$ 170,400$ & - & $\$ 123,930$ \\
\hline Product AB2 & Fall 2006 & & & & \\
\hline Raw material 3 & & $\$ 63,805$ & $\$ 58,427$ & $\$ 20,118$ & $\$ 59,498$ \\
\hline Raw material 4 & & - & $\$ 32,238$ & $\$ 16,072$ & $\$ 20,271$ \\
\hline Product $A B 3$ & Fall 2008 & & & & \\
\hline Raw material 5 & & & - & $\$ 243,000$ & $\$ 182,250$ \\
\hline Total & & $\$ 821,805$ & $\$ 954,065$ & $\$ 279,190$ & $\$ 889,962$ \\
\hline
\end{tabular}

Projected co-creation of value for FY 2010: $\$ 889,962$.

Table 4 also shows the financial outcomes for Company A from three cost reduction initiatives: AC3, AC4, and AC5. All of them consisted of the reformulation of the raw materials that Company $C$ sold to Company A. The resulting products were less expensive while maintaining quality. Company A saved a total of $\$ 107,800$ in 2008 and $\$ 272,714$ in 2009 . The projections for FY 2010 were $\$ 304,644$ in savings. The initiatives $A C 3, A C 4$, and $A C 5$ were started with a request from procurement managers at Company $A$ for the supplier to work on reducing product costs. With guidelines provided by the R\&D personnel at Company $A$, the supplier sales person asked the $R \& D$ managers at Company $C$ to reformulate the products.

Company A's total purchases from Company C were projected to remain at the same level as 2009 in 2010 due to the bad economy. The projected outcomes of joint initiatives for Company $A$ in 2010 were $\$ 359,105$, which represented $2.5 \%$ of the total purchases from Company C projected for 2010 . The value co-created for Company $A$ in Relationship AC was significantly lower than the value co-created in Relationship AB. 
Table 4 Financial outcomes for Company A from joint initiatives in Relationship AC.

\begin{tabular}{|c|c|c|c|c|c|}
\hline \multicolumn{6}{|c|}{$\begin{array}{l}\text { Value co-creation for Company A } \\
\text { Revenue generation initiatives }\end{array}$} \\
\hline \multirow{3}{*}{$\begin{array}{l}\text { Product } \\
\text { developed }\end{array}$} & \multirow{3}{*}{$\begin{array}{l}\text { Date } \\
\text { launched }\end{array}$} & \multicolumn{4}{|c|}{ Contribution $(*)$} \\
\hline & & FY 2007 & FY 2008 & FY 2009 & Projected \\
\hline & & & & & FY 2010 \\
\hline Product AC1 & Fall 2009 & - & - & $\$ 44,226$ & $\$ 35,789$ \\
\hline Product AC2 & Fall 2008 & - & $\$ 4,883$ & $\$ 5,722$ & $\$ 18,672$ \\
\hline Total & & - & $\$ 4,883$ & $\$ 49,948$ & $\$ 54,461$ \\
\hline \multicolumn{6}{|c|}{ Cost reduction initiatives } \\
\hline \multirow{3}{*}{$\begin{array}{l}\text { Cost reduction } \\
\text { initiative }\end{array}$} & $\begin{array}{l}\text { Date of } \\
\text { initiative }\end{array}$ & \multicolumn{4}{|c|}{ Cost reduction } \\
\hline & & FY 2007 & FY 2008 & FY 2009 & Projected \\
\hline & & & & & FY 2010 \\
\hline Cost initiative AC3 & Summer 2009 & - & - & $\$ 67,400$ & $\$ 92,886$ \\
\hline Cost initiative AC4 & Summer 2009 & & - & $\$ 20,514$ & $\$ 26,958$ \\
\hline Cost initiative AC5 & Summer 2008 & - & $\$ 107,800$ & $\$ 184,800$ & $\$ 184,800$ \\
\hline Total & & - & $\$ 107,800$ & $\$ 272,714$ & $\$ 304,644$ \\
\hline
\end{tabular}

Projected co-creation of value for FY 2010: $\$ 359,105$

$\left.{ }^{*}\right)$ Contribution toward the joint costs and fixed cost of Company A

\subsubsection{Value co-creation for Company $\mathrm{C}$}

Company C supplied Company A with Raw Material 6 and Raw Material 7 for manufacturing Products $A C 1$ and $A C 2$ respectively. The total increase in sales of raw materials resulting from the development of Products AC1 and AC2 were \$357,754 in 2008 and \$170,512 in 2009 (see Table 5). The sales of Raw Material 6 and Raw Material 7 in 2008 represented 1.9\% of the total volume sold to Company A. The projected sales to Company $A$ for the two products in fiscal year 2010 were $\$ 334,427$ (2.3\% of the total sales projected for 2010). Informants from Company $C$ did not provide information to measure the value co-created for their side of the relationship. However, all the managers interviewed in Company $\mathrm{C}$ indicated that the increase in sales had not been sufficient to compensate for the development costs that they had incurred. In addition, they faced constant pressure from managers in Company A to reduce prices because they were being compared to Company $B$ in terms of resources committed to the relationship. 


\subsection{Relationship AB compared with Relationship AC}

Relationship $A B$ was cross-functional and Relationship $A C$ was not. This was reflected in the type of initiatives that were conducted in each relationship. The initiatives conducted in Relationship $A B$ were focused on the development and commercialization of new products, an area that was key for Company $A$ and which required cross-functional involvement and the commitment of more resources from both firms. The initiatives conducted in Relationship AC were focused primarily on the reduction of the costs of raw materials, where there was less potential to co-create value. The total value co-created in joint initiatives for Company A from Relationship $A B$ (in terms of contribution toward the joint costs and fixed costs of Company $A$ ) in the past three years was $\$ 72.5$ million (an average of $\$ 24.2$ million/year). The projected value co-creation for Company $A$ for fiscal year 2010 was $\$ 25.9$ million, which was 1.65 times higher than the total projected purchases from Company B for 2010.

Table 5 Financial outcomes for Company C from the joint initiatives in Relationship AC.

\begin{tabular}{|c|c|c|c|c|c|}
\hline \multicolumn{6}{|c|}{ Value co-creation for Company C } \\
\hline Incremental sales & Eompany A & new prodı & eloped colla & ratively & \\
\hline \multirow{2}{*}{$\begin{array}{l}\text { Product } \\
\text { developed/raw } \\
\text { material supplied }\end{array}$} & \multirow{2}{*}{$\begin{array}{l}\text { Date } \\
\text { launched }\end{array}$} & \multicolumn{4}{|c|}{ Incremental purchases } \\
\hline & & FY 2007 & FY 2008 & $\begin{array}{l}\text { FY } 2009 \\
\text { (up to May-20) }\end{array}$ & $\begin{array}{l}\text { Projected FY } \\
2010\end{array}$ \\
\hline Product AC1 & Jan-2009 & & & & \\
\hline Raw material 6 & & - & - & $\$ 102,510$ & $\$ 148,537$ \\
\hline Product AC2 & Jan-2008 & & & & \\
\hline Raw material 7 & & - & $\$ 357,754$ & $\$ 68,002$ & $\$ 185,890$ \\
\hline Total & & - & $\$ 357,754$ & $\$ 170,512$ & $\$ 334,427$ \\
\hline
\end{tabular}

Projected co-creation of value for FY 2010: $\$ 334,427$.

The total value co-created in joint initiatives for Company A from Relationship AC in the past three years was $\$ 327,545$ (an average of $\$ 109,182$ per year). The projected value co-creation for Company $A$ for fiscal year 2010 was $\$ 359,105$. This represents $2.5 \%$ of the total purchases from Company $C$ that were projected for 2010. Relationship $A B$, which had cross-functional involvement, resulted in more value co-creation. However, given that Company $C$ sold higher volumes to Company $A$ than Company $B$ ( $\$ 18.5$ million vs. $\$ 16.7$ million respectively in 2008 ) and was a larger company than Company $B$, there was the potential for Company $\mathrm{C}$ to co-create more value had management made the decision to do so by investing in the relationship.

\subsection{Measurement of value co-creation in Relationship DE}

Only one cost reduction initiative was conducted in Relationship DE, which consisted of the redesign of the distribution system for the products supplied from Company $D$ to Company $E$. The distribution system was transformed from a direct store delivery (DSD) method to a warehouse delivery method in April of 2008. In the direct to store delivery method, the products from Company D were delivered to the retail stores, bypassing the warehouses of Company $E$. Company D owned a private fleet of trucks 
and had a pool of drivers. The drivers not only transported the products but also placed them on the store shelves and negotiated purchase orders with the store managers. Therefore, the truck drivers were able to influence the quantities ordered, for which they received a sales commission from Company $D$. Many times this led to more products being sold and delivered to the retail stores than were purchased by consumers. Because the products were highly perishable, this led to a significant amount of product returns from Company E to Company D. No intermediate stocking location was used in the DSD distribution system so the lead times to the stores were long. Trucks had to be dispatched frequently from the warehouses of Company $D$ to the customer in order to prevent stock-outs, which in turn increased the transportation costs.

In the new system, products were transported in Company D's trucks to Company E's warehouses. The products were stored in the warehouses and then transported to the retail stores using Company E's private fleet. More frequent deliveries from the warehouses to the stores could be made and the distances were shorter. The costly emergency deliveries from Company D's warehouses to the stores were eliminated because there were safety stocks located in the retailer's warehouses. Both variable transportation costs such as gas and maintenance, and fixed transportation costs such as trucks and salaries were reduced. Product returns were reduced because the drivers of Company $D$ did not interact with the store managers and the replenishment of products was managed centrally in Company $\mathrm{E}$. Stock-outs at the store level were reduced and the freshness of the product improved because of the higher frequency of deliveries to the stores. The most significant cost increase experienced by Company B was the hiring of a new broker. A retail broker was needed to stock products on the stores' shelves and to design promotions. Warehousing costs did not increase significantly for Company $E$ because the operations were leveraged with those performed for other suppliers.

The idea for the new distribution initiative DE1 originated in Company $E$, which had implemented a similar distribution system with other suppliers. The planning and the implementation of the initiative required the participation of representatives of multiple functions from both the supplier and the customer. The distribution and transportation managers from both firms were responsible for evaluating the feasibility of the project, designing the new distribution system and establishing the new ordering procedures. The quality managers from the supplier were involved to ensure that the quality standards were met. The marketing representatives of the supplier and the customer interacted with the employees from the brokerage firm to establish the procedures for stocking products in the store. Company E's buyers and Company D's sales managers forecasted the impact that the increased availability and the cheaper price of the products would have on sales. The buyers of the customer and the operations managers of the supplier coordinated the replenishment activities and the deployment of stocks. The transition from one system to the other required close coordination across the functions of both companies to avoid disruptions in distribution. The financial outcomes from the initiatives conducted in Relationship DE are estimated next. 


\subsubsection{Value co-creation for Company $D$}

The new distribution initiative DE1 was implemented in April 2008, and it improved the profitability for Company $D$ by $\$ 4.1$ million in fiscal year 2009. The reduction in product returns from Company $E$ to Company $D$ represented $56 \%$ of the cost savings. The reduction of truck driver salaries represented $23 \%$ of the cost savings. The elimination of the sales commissions that were paid to the truck drivers represented $14 \%$ of the cost savings. The reduction in transportation costs was $7 \%$ as a result of fuel and maintenance cost savings, and a reduction in the size of the private fleet. The additional expenses generated by hiring a new brokerage firm were equal to $31 \%$ of the costs saved. Based on the experience gained in this project, Company D's management was planning to approach other customers about implementing warehouse delivery.

The margin-to-sales ratio was used to compare the value co-created in relationships DE and DF. The margin-to-sales ratio had an overall positive trend over the months. A least squares method was used to estimate the trend. The slope of the trend line was $2.2 \%$, meaning that the margin-to-sales ratio tended to increase $2.2 \%$ per month $\left(R^{2}=0.57\right.$ ). The margin-to-sales ratio increased $29.8 \%$ during 2009 to $9.3 \%$. These results were validated with the assessments from three sales managers and one finance manager from Company $D$, and a buyer from Company $E$. They agreed that since the implementation of the new distribution system and due to the closer relationship that they had developed, the profitability of both companies had increased significantly.

\subsubsection{Value co-creation for Company $E$}

In the new distribution system, Company E performed distribution operations such as warehousing, transportation to the stores, and material handling that were not previously performed. The increase in the retailer's distribution costs was offset by an average 7\% reduction in Company D's prices to Company E. The savings from the price reduction for Company $E$ were projected to be $\$ 1.0$ million for fiscal year 2010. According to managers in Company $E$, the savings were used to reduce the prices to the endconsumer, which in turn led to increased sales for both Company D and Company E. Additionally, the procurement activities were centralized in Company $\mathrm{E}$, leading to a reduction of the store managers' workload and improvements in the procurement function.

\subsection{Measurement of value co-creation in Relationship DF}

No joint initiatives were conducted in the relationship between Company $\mathrm{F}$ and Company $\mathrm{D}$. The buyer at Company $\mathrm{F}$ mediated the communication between the representatives of the different functions on both sides. This person expected good levels of service, quality and price from Company $D$, but did not want to participate in joint initiatives. There was some level of communication between the distribution functions from both companies but only for issues related to distribution at an operational level. The retailer also provided point-of-sales data for a fee, but the analysis of the data was left to the supplier. Management at the supplier had not been able to develop new commercial opportunities from the data 
because the retailer had not provided the necessary assistance. Company D's profitability report for Company $\mathrm{F}$ was constructed for fiscal year 2009 on a monthly basis. The margin-to-sales ratio for year 2009 was $4.8 \%$, which is lower than the margin-to-sales ratio of Company $E$.

\subsection{Relationship DE compared with Relationship DF}

At the time that we did the research the company did not have the capability of measuring the profitability of customers using revenues minus avoidable costs. Consequently, we worked with management to identify on a special study basis the margins generated by the two retailers studied. Management believed that the margin-to-sales ratio captured in a realistic way the business with these two retailers. As a result of this research, management has invested in the capability of generating profitability reports for all key customers, based on revenues minus avoidable costs, to be used on an ongoing basis. Relationship DE had high levels of cross-functional involvement. Managers from different functions from both companies participated in the new distribution initiative DE1 that increased the profitability for Company $D$ by $\$ 4,119,500$. No joint initiatives were detected in Relationship DF. The margin-to-sales ratio for Company $E$ was higher than for Company F ( $9.3 \%$ vs. $4.8 \%$ respectively). The margin-to-sales ratio of Company $\mathrm{E}$ had increased 2.2\% monthly in average over year 2009, while there was no evidence of an increase in Company F's margin-to-sale ratio in that same period of time. Therefore, the notion that value co-creation is fostered in cross-functional buyer-supplier relationships was supported by the findings.

The annual sales to Company F were $\$ 42.9$ million in 2009 , compared to $\$ 14.2$ million to Company $E$ in same period. The number of Company F's stores that sold Company D's products increased year after year. In contrast, all Company E stores were selling Company D's products. It would appear that Company $\mathrm{F}$ could achieve considerable growth and value co-creation if managers decided to collaborate with Company D using cross-functional teams.

\subsection{Changes in managers' perceptions and behaviors toward the relationships}

The financial measurements of value co-creation described in this paper were provided to managers in Company A and Company D four months after the 2009 fiscal year end. Seventeen months later, further interviews were conducted in order to assess the changes in managers' perceptions and behaviors toward the relationships that occurred as a result of having the new financial information.

In Company $A$, the relationship with supplier Company $B$ continued to strengthen, while the relationship with supplier Company $C$ became "totally transactional" (according to one of Company A's managers). Cross-functional initiatives between Company $A$ and Company $B$ led to the development of a new product that was launched in 2010, and which at the time of the interviews had generated $\$ 250,000$ in revenue for Company A. As the VP of Supply Chain Management of Company A explained, new opportunities to co-create value were discovered: "Company $B$ is now engaged in even more things than just providing raw ingredients to the back of our restaurants. Company $B$ is now helping us to reorganize the retail area within our restaurants. They are a big player in the retail industry, so they 
have great consumer insights for us. For example, their marketing and finance people are interacting with our procurement, logistics, and marketing people to determine what products to sell and how to display them in our restaurants." Purchases of Company A from Company B in 2010 remained at similar levels to 2009 due to the adverse general economic conditions, but as Company A's Procurement Director said: "this is not necessarily a bad thing given that these have been tough times for our overall business."

Company A's purchases from Company $C$ had "fallen dramatically" according to the Procurement Director of Company A. He stated that: "By the end of this year, we will have probably purchased only $25 \%$ of the volume that we purchased from them last year." The main reason behind this decision was the lack of willingness in Company $\mathrm{C}$ to involve multiple functions in the relationship to foster value cocreation. The manager explained: "I have a very good personal relationship with my account manager at Company C, I really like him a lot. But you need more than one person to create a team. They lost $75 \%$ of their business because they are not interested in interacting with us on multiple fronts. We have not heard anything from their R\&D group or from their marketing group." The sales that supplier Company C lost were captured by other suppliers: "From that $75 \%$ of business that Company C lost, probably half of it was allocated to another supplier that has engaged in a more cross-functional relationship with us. They stepped up to the table with innovation. They are engaging their R\&D and manufacturing managers with our people to develop new product offerings and to find better packaging methods. Last year we purchased $\$ 2.0$ million from this supplier and we have quadrupled this amount." Managers in Company $A$ started using financial measures to evaluate value co-creation in strategic relationships with suppliers of other categories of products.

Based on this research, Managers in Company $D$ implemented profitability reports for all major customers. Company D's VP of Sales said: "now we are able to analyze the profitability with Company E and Company $\mathrm{F}$ on a regular basis. The profitability reports are giving everybody in our company better visibility of where our efforts go and the returns from our investments. Our functional managers now know how much money each customer account is making or loosing. Every month they have to explain the reasons for the results and what their functions will do to sustain or improve the profitability of each relationship. For example, we discovered that we were discounting one of our key products too much, so we put a trade marketing team in place to better coordinate promotions with Company F." Relationship DF was becoming more cross-functional. Company D's managers were being given access to more individuals in Company $F$, rather than having to channel all communications through the single buyer as in the past. "They are bringing other managers into the relationship now, which is creating more opportunities to work with people with different backgrounds. This is good."

Relationship DE was "still very cooperative," according to the President of Company D. "Even though our margins have been lower this year due to a general increases of our raw materials' prices, our relationship with Company E's top people is very good and we keep working on cross-functional initiatives." New opportunities to increase the profitability of the relationship were found as a result of having 
profitability reports available. For example, the product delivery frequency from Company $D$ to Company $E$ was changed from five times a week to three times a week: "the costs of delivering five days a week were so high that we were not reaching our profit goals. We analyzed all the direct costs involved in this operation and we changed our distribution frequency. This was certainly done in collaboration with managers in Company E. Our VP of sales along with our people from logistics, quality, and finance, interacted with their account manager and their logistics representatives. The team found that we could achieve the same product availability delivering three days a week. Both companies saved money by implementing these changes." Product promotion plans were still being developed in collaboration with managers of the two companies. Company D's VP of sales said: "in order to develop the right promotions, at the right time, and in the right place, we need the involvement of multiple functions and the help that Company E provides us."

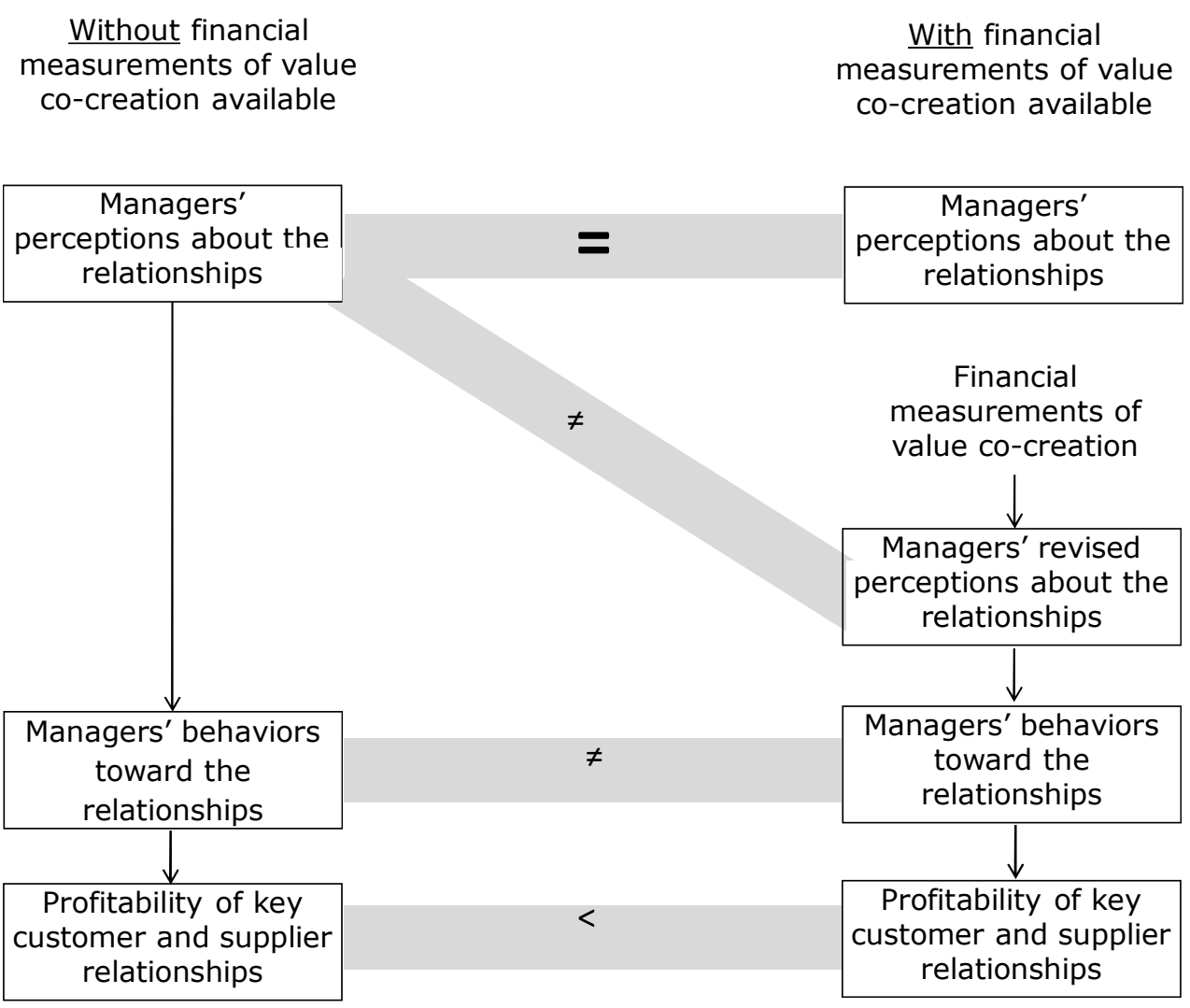

Fig. 2 Changes in managers' perceptions and behaviors toward customer and supplier relationships.

Managers perceived that the relationships with more cross-functional involvement were more profitable before this research was conducted. However, it was not until managers received the financial outcomes of the initiatives that were conducted in each relationship that they realized the magnitude of the difference in profitability. This is illustrated with a quotation from the VP of Supply Chain Management of Company A: "We knew that Company A was a good partner and that Company B was not as good. The financial measurements of value co-creation enabled us to confirm what we already 
suspected." Another manager added: "The financial measurements confirmed our belief that for key suppliers to do more business with us, and to maintain business with us, they need to be crossfunctional."

In line with Sánchez-Fernández and Iniesta-Bonillo (2007) and Brock Smith and Colgate (2007), we found that managers' perceptions of value are conditional (depend on the individual and the situation), relative, and dynamic (change over time). Fig. 2 illustrates how managers changed their perceptions and behaviors toward the relationships after the financial information was made available to them: financial information was another input to the cognitive process by which mangers formed (or adjusted) their perceptions about the value of a business-to-business relationship. The change in managers' perceptions drove changes in behaviors toward customers and suppliers, which ultimately affected the profitability of the relationships.

\section{Conclusions}

Value co-creation was higher in Relationship $A B$ and Relationship DE, where cross-functional, cross-firm teams were involved. For example, the projected value co-creation for Company A for fiscal year 2010 from Relationship $A B$, which had cross-functional involvement, was $\$ 25.9$ million, while it was $\$ 359,105$ from Relationship AC. Relationship DE had cross-functional involvement and was more profitable for Company D than Relationship DF. The margin-to-sales ratio for Company E was $9.3 \%$ vs. $4.8 \%$ for

Company $F$. The results of the measurements of value co-creation cannot be attributed to the relative importance of the relationships that were compared in each pair, since all relationships were viewed as strategic by management (see Table 1 ).

The involvement of major corporate functions in business-to-business relationships was found to create conditions that enable the co-creation of value. Managers should consider using cross-functional, crossfirm teams to increase the profitability of relationships with strategic customers and suppliers. The development of cross-functional, cross-firm teams requires the commitment of a large amount of resources from both sides of a relationship. Therefore, cross-functional relationships should be developed only with strategic customers and suppliers that have the willingness and/or the capabilities to work in crossfunctional teams. It is in these strategic relationships where the best opportunities to co-create value exist. A transactional approach, with no direct interaction between the major functions on both sides of the relationship, is usually the most profitable way to manage relationships with low potential to co-create value (Lambert, 2010).

Management should segment customers and suppliers considering financial information such as the profit impact and the potential growth of each relationship. This research showed that an individual's perceptions about the value of a customer or a supplier relationship can change when financial information is made available. The change in managers' perceptions drove changes in behaviors toward customers and suppliers. This was confirmed based on interviews conducted 17 months after the original research. 
Using financial measurements of value co-creation is important in business-to-business contexts because an individual manager is rarely familiar with all of the initiatives that occur within a relationship (which could encompass initiatives such as product development, manufacturing process improvement, quality improvement, and the provision of market information). Even if managers were familiar with all of these initiatives, they may lack the specialized knowledge required to form an accurate perception of the value generated without financial measurements. A method for measuring value co-creation in financial terms was described. Managers can use this method to identify the relationships that co-create the most value in order to assign resources in the most profitable way. Even if the measurement of value co-creation is not $100 \%$ accurate, the activity of gathering members from all the involved functions from both sides of a relationship to discuss and measure value co-creation can lead to a better understanding of the value being co-created in the relationship. Quoting Brown et al. (2005, p.18): "approximate answers to important problems or issues are just as useful (if not more useful) than precise answers to wrong, well-defined, narrow problems." Additionally, the effort can reinforce management's confidence that the focus of the relationship is on value co-creation and that their contributions will be rewarded.

\subsection{Limitations and research opportunities}

This exploratory research was designed to enable an in-depth comparison of the value co-created in the relationships under study. High levels of internal validity and construct validity were ensured with a sample size of 46 managers at the informant level of analysis, with 11 initiatives at the cross-functional initiative level of analysis, and with a theoretical sampling approach designed to control for the influence of the relative importance of each relationship on the measurements of value co-creation (Carter et al., 2007; Miles \& Huberman, 1994; Ragin, 1987). Four additional interviews were conducted 17 months later to determine how managers' perceptions and behaviors had changed. However, four case studies at the relationship level are not sufficient to enable generalization of the findings. It is difficult to find executives to participate in this type of research because of the level of trust that is necessary on both sides of the relationship if managers are going to share the necessary financial information. More research should be conducted with a larger sample of firms from other industries to further validate the conclusions.

The access to financial data from both sides of the four relationships was not possible for confidentiality reasons. Unless there is deep trust in a relationship there may be a fear that the other side will try to use the financial knowledge obtained for short-term gains. This concern makes it difficult to identify companies to participate in research projects that involve sharing financial information. Also, generating the type of financial reports that are necessary to measure value co-creation can be time consuming for managers. Based on our findings, the benefits of measuring value co-creation outweigh the costs. However, this needs to be confirmed with further research. 
After measuring the value co-created, the gains should be shared in order to create incentives for managers to continue dedicating resources to the relationship. Determining the contribution of each party to the outcomes can be a challenge. A future research opportunity is the identification of a method for equitably sharing the financial gains co-created in a relationship.

Measurement of the potential of a relationship to co-create value in the future can be challenging. For example, there might be a saturation effect that reduces the rate at which value is co-created as more resources are assigned to the relationship. Although our method, based on current initiatives, provides managers with some guidance related to potential opportunities in existing relationships, research is needed to develop a method to estimate the potential for co-creating value.

\subsection{Implications for academics and managers}

The findings of this research can be useful for academics and managers. Typically, scholars use measures of value that are based on managers' perceptions (Mezias \& Starbuck, 2003). The limitations of relying on such measurements of value were highlighted, and a method for measuring value in financial terms was presented and applied. This method incorporated recommendations from the industrial marketing literature that are rarely combined in empirical research. First, cross-functional teams included representatives of functions such as Finance, Logistics, Operations, Purchasing, and $R \& D$, as well as Sales, Marketing and IT, which was a much broader conceptualization than the limited view of cross-functional teams that is predominant in the marketing literature (Lambert, 2010). Second, value co-creation was measured and compared from the perspective of both the supplier and the customer (Ulaga, 2001). Third, the initiatives conducted within the relationships were the basis for measuring value co-creation (Ford \& McDowell, 1999), Fourth, the initiatives were identified and validated by managers in the various organizational functions of the two firms (Hogan, 2001). Fifth, multiple dimensions of value co-creation such as revenue generation initiatives and cost reduction initiatives were captured in the measurements (Ulaga, 2003). Finally, the changes in managers' perceptions and behaviors toward the relationships were assessed 17 months after the financial measures of value co-creation were provided to them (Eggert et al., 2006; Ryals, 2005).

Scholars have called for more research on value co-creation in a business-to-business context (Lindgreen \& Wynstra, 2005; Lusch \& Vargo, 2006; Payne et al., 2008) ${ }^{3}$. This research provides empirical support for the idea that implementing cross-functional, cross-firm teams is key for

\footnotetext{
3 This paper is a contribution toward two of the six perspectives for future research on value in business markets identified by Lindgreen and Wynstra (2005). First, the "value analysis and the value of relationships" perspective was addressed by showing an approach to measure the "return on a relationship" in financial terms. Second, the "value creation and the value of relationships" perspective was addressed by providing an answer to the question: "to what extent do different interaction processes between suppliers and customers [such as cross-functional, cross functional team interactions] exist?" (p. 744).
} 
developing buyer-supplier relationships that co-create value, which is absent in the literature. While managers in company A had an appreciation for which relationship in each pair was more profitable, they underestimated the magnitude of the difference before being shown the financial results. The financial measurements changed their perceptions as well as how they treat the companies involved. In addition, they made it a requirement that any supplier wanting to be strategic must have the willingness and capability to think in terms of value co-creation and work in cross-functional teams. Managers can segment customers and suppliers based on the profitability of each relationship and the potential for growth. A large number of supplier and customer management decisions are made without financial measurements of value (Lambert, 2008). As a result, the benefits of developing cross-functional relationships with key customers and suppliers are underestimated. The measurement model shown in Fig. 1 can be used to demonstrate the value of buyer-supplier relationships in order to gain the commitment of all the major functional representatives. Managers that embrace the measurement of value co-creation and implement cross-functional teams can achieve a competitive advantage not only for their companies but also for their key customers and suppliers.

It has been stated that the role and the influence of the marketing function is diminishing in companies: "Marketers are being marginalized, in the sense that many strategically important aspects of marketing (e.g.: pricing, ad budgeting, new product decisions) are being taken away by other functions in the organizations" (Brown et al., 2005, p. 11). By promoting cross-functional, cross-firm relationships, and including financial measures in the evaluation of relationship performance, marketing managers have the opportunity to take a leadership role in improving the competitiveness of their corporations through the co-creation of value with key customers and suppliers.

\section{Acknowledgment}

The authors acknowledge the Global Supply Chain Forum for supporting this research.

\section{References}

Anderson, J., Jain, D., \& Chintagunta, P. (1993). Customer value assessment in business markets: A state-of-practice study. Journal of Business-to-Business Marketing, 1(1), 3-29.

Baba, M. L. (1988). Two sides to every story: An ethnohistorical approach to organizational partnerships. City \& Society, 2(2), 71-104.

Beverland, M., \& Lindgreen, A. (2010). What makes a good case study? A positivist review of qualitative case research published in Industrial Marketing Management, 1971-2006. Industrial Marketing Management, 39(1), 56-63.

Brock Smith, J., \& Colgate, M. (2007). Customer value creation: A practical framework. Journal of Marketing Theory and Practice, 15(1), 7-23. 
Brown, S. W., Webster, F. E., Jr., Steenkamp, J. E. M., Wilkie, W. L., Sheth, J. N., Sisodia, R. S., Kerin, R. A., et al. (2005). Marketing renaissance: Opportunities and imperatives for improving marketing thought, practice, and infrastructure. Journal of Marketing, 69 (4), 1-25.

Campion, M. A., Medsker, G. J., \& Higgs, A. C. (1993). Relations between work group characteristics and effectiveness: Implications for designing effective work groups. Personnel Psychology, 46(4), 823-850.

Carter, C. R., Ellram, L. M., \& Tate, W. (2007). The use of social network analysis in logistics research. Journal of Business Logistics, 28(1), 137-168.

Cova, B., \& Salle, R. (2008). Marketing solutions in accordance with the S-D logic: Co-creating value with customer network actors. Industrial Marketing Management, 37 (3), 270-277.

Doyle, P. (2000). Value-based marketing. Journal of Strategic Marketing, 8(4), 299-311.

Eggert, A., \& Ulaga, W. (2010). Managing customer share in key supplier relationships. Industrial Marketing Management, doi:10.1016/j.indmarman.2010.03.003.

Eggert, A., Ulaga, W., \& Schultz, F. (2006). Value creation in the relationship life cycle: A quasilongitudinal analysis. Industrial Marketing Management, 35(1), 20-27.

Eisenhardt, K. M. (1989). Building theories from case study research. Academy of Management Review, 14(4), 532-550.

Ellram, L. M. (1996). The use of the case study method in logistics research. Journal of Business Logistics, $17(2), 93-138$.

Ford, D., \& McDowell, R. (1999). Managing business relationships by analyzing the effects and value of different actions. Industrial Marketing Management, 28(5), 429-442.

Hackman, J. R. (1987). The design of work teams. In J. Lorsch (Ed.), Handbook of organizational behavior. Englewood Cliffs, NJ: Prentice-Hall.

Håkansson, H., \& Ford, D. (2002). How should companies interact in business networks? Journal of Business Research, 55(2), 133-139.

Helgesen, $\varnothing$. (2007). Customer accounting and customer profitability analysis for the order handling industry - A managerial accounting approach. Industrial Marketing Management, 36(6), 757-769.

Hirunyawipada, T., Beyerlein, M., \& Blankson, C. (2010). Cross-functional integration as a knowledge transformation mechanism: Implications for new product development. Industrial Marketing Management, 39(4), 650-660.

Hogan, J. (2001). Expected relationship value. Industrial Marketing Management, 30(4), 339-351. 
Jüttner, U., Christopher, M., \& Baker, S. (2007). Demand chain management-integrating marketing and supply chain management. Industrial Marketing Management, 36(3), 377-392.

Kaplan, R. S., \& Norton, D. P. (1996). Using the Balanced Scorecard as a Strategic Management System. Harvard Business Review, 74(1), 75-85.

Kumar, V., \& Shah, D. (2009). Expanding the role of Marketing: from customer equity to market capitalization. Journal of Marketing, 73(6), 119-136.

Lambert, D. M. (2008). Supply chain management: Processes, partnerships, performance (3rd Ed). Sarasota, FL: Supply Chain Management Institute.

Lambert, D. M. (2010). Customer relationship management as a business process. The Journal of Business and Industrial Marketing, 25(1), 4-17.

Lambert, D. M., \& Sterling, J. U. (1987). What types of profitability reports do marketing managers receive? Industrial Marketing Management, 16(4), 295-303.

Lambert, D. M., \& García-Dastugue, S. (2006). Cross-functional business process for the implementation of service-dominant logic. In R. F. Lusch, \& S. L. Vargo (Eds.), Toward a service-dominant logic of marketing: Dialog, debate, and directions. ME Sharpe: Armonk, NY.

Lincoln, J. R., \& Zeitz, G. (1980). Organizational properties from aggregate data: Separating individual and structural effects. American Sociological Review, 45(3), 391-408.

Lindgreen, A., \& Wynstra, F. (2005). Value in business markets: What do we know? Where are we going? Industrial Marketing Management, 34(7), 732-748.

Lusch, R. F., \& Vargo, S. L. (2006). Service-dominant logic: Reactions, reflections and refinements. Marketing Theory, 6(3), 281-288.

McDonald, M., Rogers, B., \& Woodburn, D. (2000). Key customers: How to manage them profitably. Oxford: Butterworth-Heinemann.

Meredith, J. (1998). Building operations management theory through case and field research. Journal of Operations Management, 16(4), 441-454.

Mezias, J. M., \& Starbuck, W. H. (2003). Studying the accuracy of managers' perceptions: A research odyssey. British Journal of Management, 14(1), 3-17.

Miles, M. B., \& Huberman, M. (1994). Qualitative data analysis: An expanded sourcebook. Thousand Oaks, CA: Sage Publications.

Moorman, C., \& Lehmann, D. R. (2004). Assessing marketing strategy performance. Cambridge, MA: 
Marketing Science Institute.

Narver, J. C., \& Slater, S. F. (1990). The effect of a market orientation on business profitability. Journal of Marketing, 54(4), 20-35.

Payne, A., \& Frow, P. (2005). A strategic framework for customer relationship management. Journal of Marketing, 69(4), 167-176.

Payne, A. F., Storbacka, K., \& Frow, P. (2008). Managing the co-creation of value. Journal of the Academy of Marketing Science, 36(1), 83-96.

Phillips, L. W. (1981). Assessing measurement error in key informant reports: A methodological note on organizational analysis in Marketing. Journal of Marketing Research, 18(4), 395-415.

Ragin, C. C. (1987). The comparative method: Moving beyond qualitative and quantitative strategies. Berkeley, CA: University of California Press.

Ramirez, R. (1999). Value co-production: Intellectual origins and implications for practice and research. Strategic Management Journal, 20(1), 49-65.

Rust, R. T., Ambler, T., Carpenter, G. S., Kumar, V., \& Srivastava, R. K. (2004). Measuring marketing productivity: Current knowledge and future directions. Journal of Marketing, 68(4), 76-89.

Ryals, L. (2005). Making customer relationship management work: The measurement and profitable management of customer relationships. Journal of Marketing, 69(4), 252-261.

Ryals, L., \& Knox, S. (2001). Cross-functional issues in the implementation of relationship marketing through customer relationship management. European Management Journal, 19(5), 534-542.

Sánchez-Fernández, R., \& Iniesta-Bonillo, M.À. (2007). The concept of perceived value: A systematic review of the research. Marketing Theory, 7(4), 427-451.

Sheth, J., \& Sharma, A. (1997). Supplier relationships: Emerging issues and challenges. Industrial Marketing Management, 26(2), 91-100.

Storbacka, K., Ryals, L., Davies, I., \& Nenonen, S. (2009). The changing role of sales: Viewing sales as a strategic, cross-functional process. European Journal of Marketing, 43(7/8), 890-906.

Stuart, F. I., McCutcheon, D., Handfield, R. B., McLachlin, R., \& Samson, D. (2002). Effective case research in operations management: A process perspective. Journal of Operations Management, 20(5), 419-433.

Trent, R. J., \& Monczka, R. M. (1994). Effective cross-functional sourcing teams: Critical success factors. International Journal of Purchasing and Materials Management, 30 (4), 3-11. 
Troy, L. C., Hirunyawipada, T., \& Paswan, A. K. (2008). Cross-functional integration and new product success: An empirical investigation of the findings. Journal of Marketing, 72(6), 132-146.

Tuli, K. R., Kohli, A. K., \& Bharadwaj, S. G. (2007). Rethinking customer solutions: From product bundles to relational processes. Journal of Marketing, 71(3), 1-17.

Ulaga, W. (2001). Customer value in business markets. Industrial Marketing Management, 30(4), 315319.

Ulaga, W. (2003). Capturing value creation in business relationships: A customer perspective. Industrial Marketing Management, 32(8), 677-693.

Ulaga, W., \& Chacour, S. (2001). Measuring customer-perceived value in business markets. Industrial Marketing Management, 30(6), 525-540.

Ulaga, W., \& Eggert, A. (2006). Value-based differentiation in business relationships: Gaining and sustaining key supplier status. Journal of Marketing, 70(1), 119-136. Vargo, S. L., \& Lusch, R. F. (2004). Evolving to a new dominant logic for marketing. Journal of Marketing, 68(1), 1-17.

Webster, F. E. (1992). The changing role of marketing in the corporation. Journal of Marketing, 56(4), 117.

Yin, R. K. (1989). Case study research. Thousand Oaks, CA: Sage Publications.

Matias G. Enz is a Lecturer in Supply Chain Management at Cranfield University. His research interests are in the areas of supply chain management, business relationships and inter-organizational collaboration. He received his doctorate (PhD) in Business Logistics from The Ohio State University and holds an Industrial Engineering degree from Universidad Nacional de Rosario (Argentina).

Douglas M. Lambert holds the Raymond E. Mason Chair, is Professor of Marketing and Logistics, and Director of The Global Supply Chain Forum, Fisher College of Business, at The Ohio State University. His research interests include supply chain management, the role of partnerships in achieving a competitive advantage, and measuring and selling value. He has published more than 100 articles in numerous journals including Harvard Business Review, Journal of Business Logistics, and Journal of Retailing, and is editor of the book Supply Chain Management: Processes, Partnerships, Performance which is in its 3rd edition. 